$\begin{array}{lll}\text { ISSN:1991-8178 } & \text { APPLRALIAN JOURNAL OF BASIC AND } \\ \text { EISSN: } 2309-8414 & \text { DOI: } 10.22587 / \text { ajbas.2017.11.14.17 } \\ \text { Journal home page: www.ajbasweb.com } & \text { Bustralian and Applied Sciences }\end{array}$

\title{
Effect of Spacing on the Form Factor of Pinus taeda $L$.
}

${ }^{1}$ João Maurício Pacheco, ${ }^{1}$ Afonso Figueiredo Filho, ${ }^{1}$ Andrea Nogueira Dias, ${ }^{1}$ Sebastião do Amaral Machado, ${ }^{2}$ Rodrigo Lima, ${ }^{2}$ Marcelo Roveda

${ }^{1}$ State University of West Center (UNICENTRO), Department of Forest Engineering. Address: PR 153, Km 07, Riozinho, 84500-000, Irati, Paraná, Brazil.

${ }^{2}$ Federal University of Paraná (UFPR), Department of Forest Engineering. Address: 900, Prefeito Lothário Meissner Avenue, Jardim Botânico, 80210-170, Curitiba, Paraná, Brazil.

\section{Address For Correspondence:}

João Maurício Pacheco, State University of West Center (UNICENTRO), Department of Forest, Engineering. Address: PR 153, Km 07, Riozinho, 84500-000, Irati, Paraná, Brazil. Tel: +55(48)9917-9786

E-mail: pachecoflorestal@gmail.com

\section{A R T I CLE I N F O \\ Article history: \\ Received 12 October 2017 \\ Accepted 22 November 2017 \\ Available online 6 December 2017}

Keywords:

living space, treatments and effect of spacing.

\begin{abstract}
A B S T RA C T
This study aimed to evaluate the effect of spacing on the shape of the stem of Pinus taeda L. at nine years old. The experiment with 9 different spacings covering areas 1 to $16 \mathrm{~m}^{2}$ was installed in the country of Irati, Paraná. The data from the nine treatments were grouped into nine classes of diameter. The volume was obtained by the method of Smalian, using nine trees to represent each treatment by diameter classes, totaling 81 trees. The form factor was calculated to express the form of stems and completely randomized design was used to verify the influence of spacing on the shape of the trunk. It was observed in the denser spacing that form factor tends to be larger, ie, they have more cylindrical trunks compared to less dense spacing. The maximum value was found in the spacing of $1 \mathrm{~m}^{2}(0,645)$ and the lowest one in the spacing $10,5 \mathrm{~m}^{2}(0,397)$, corresponded to a difference of $38,54 \%$. The spacing around $7,5 \mathrm{~m}^{2}$ per tree seemed appropriate to reduce the effect of spacing of the trunk form of Pinus taeda L.
\end{abstract}

\section{INTRODUCTION}

The genus Pinus along with the genus Eucalyptus are the two most common genera planted in Brazil. These plantations are intended to provide raw material to meet the needs of the domestic and international markets, but mainly domestic market.

Dossa (2005) mentioned that the loblolly pine is the most widely planted species in southern Brazil due to its edaphoclimatic adaptations in the region. Given its rapid growth and good quality wood, it is used in several industries, generating a plurality of product, in addition to withstand extreme cold temperatures, characteristic of southern Brazil.

The volume is one of the most important forms of information to the knowledge of forest potential, wherein the individual volume provides a starting point for evaluating the content of woody forest stands (MACHADO et al., 2005). Many tools have been developed over the years to estimate this variable, including: form factors, form quotients, volume equations, ratio of equations and taper functions.

Schneider e Schneider (2008) claim that the determination of the form factor is an important practice when you want to estimate the tree volume. Many authors have been using this tool, including, De Cesaro et al. (1994), Macedo et al. (2005), Flach (2007), Vilas Bôas et al. (2009), etc.

Open Access Journal

Published BY AENSI Publication

(C) 2017 AENSI Publisher All rights reserved

This work is licensed under the Creative Commons Attribution International License (CC BY). http://creativecommons.org/licenses/by/4.0/

\section{(c) (i) Open Access}

To Cite This Article: João Maurício Pacheco, Afonso Figueiredo Filho, Andrea Nogueira Dias, Sebastião do Amaral Machado, Rodrigo Lima, Marcelo Roveda., Effect of Spacing on the Form Factor of Pinus taeda L. Aust. J. Basic \& Appl. Sci., 11(14): 139-143, 2017 
The form factor can be considered one of the most common and oldest ways to estimate the individual tree volume. It is also important to understand that conicity effect the degree of utilization of the wood mainly for sawmill and veneer uses.

As the form factor become closer to 1, more cylindrical is the tree trunk. Factors equal to 1 are not obtained, since this would imply that the tree shape would be a perfect cylinder (FINGER, 2006).

Figueiredo Filho (1991) stated that the quality of the site affects the form of the shaft, where in low-capacity sites, trees typically have larger taper or undesirable forms, in addition to growth changes in diameter of the shaft, and productive sites. Growth is more concentrated in the tree canopy, whereas in poor sites, the growth tends to be uniformly distributed.

Finger (2006) mentioned that the factor of artificial form can be obtained by dividing the real volume of the tree (full or partial), taken in relation to the volume of a cylinder whose height and diameter at breast height $(\mathrm{DBH})$ are equal to the considered tree.

This research aimed to evaluate the effect of spacing on the trunk of Pinus taeda L. trees, in the South Central region of Paraná.

\section{MATERIAL AND METHODS}

The experiment was installed on the campus of the Universidade Estadual do Centro-Oeste (UNICENTRO) in the municipality of Irati, State of Parana, Brazil. The experimental design for installation was randomized blocks, with nine treatments and five repetitions. The spacing used contemplated useful areas of $1,0 \times 1,0 \mathrm{~m} ; 2,0$ x 1,0 m; 2,0 x 2,0 m; 3,0 x 2,5 m; 3,0 x 3,0 m; 3,5 x 3,0 m; 4,0 x 3,0 m; 4,0 x 3,5 m and 4,0 x 4,0 m. Figure 1 shows how the treatments are arranged in the area.

\begin{tabular}{|c|c|c|c|c|c|c|c|c|c|}
\hline Block 1 & $3,0 \times 3,5$ & $3,0 \times 3,0$ & $1,0 \times 1,0$ & $4,0 \times 3,0$ & $4,0 \times 3,5$ & $2,0 \times 1,0$ & $3,0 \times 2,5$ & $4,0 \times 4,0$ & $2,0 \times 2,0$ \\
\hline Block 2 & $4,0 \times 3,5$ & $3,0 \times 2,5$ & $4,0 \times 3,0$ & $4,0 \times 4,0$ & $3,0 \times 3,5$ & $1,0 \times 1,0$ & $2,0 \times 2,0$ & $2,0 \times 1,0$ & $3,0 \times 3,0$ \\
\hline Block 3 & $3,0 \times 2,5$ & $4,0 \times 3,0$ & $3,0 \times 3,5$ & $1,0 \times 1,0$ & $3,0 \times 3,0$ & $4,0 \times 3,5$ & $2,0 \times 2,0$ & $2,0 \times 1,0$ & $4,0 \times 4,0$ \\
\hline Block 4 & $3,0 \times 2,5$ & $4,0 \times 4,0$ & $3,0 \times 3,0$ & $2,0 \times 2,0$ & $3,0 \times 3,5$ & $4,0 \times 3,5$ & $2,0 \times 1,0$ & $1,0 \times 1,0$ & $4,0 \times 3,0$ \\
\hline Block 5 & $2,0 \times 2,0$ & $1,0 \times 1,0$ & $2,0 \times 1,0$ & $3,0 \times 3,0$ & $4,0 \times 3,5$ & $3,0 \times 2,5$ & $3,0 \times 3,5$ & $4,0 \times 3,0$ & $4,0 \times 4,0$ \\
\hline
\end{tabular}

Fig. 1: Distribution of treatments $(\mathrm{m} \times \mathrm{m})$ in the experimental area.

The size of each treatment varies due to the number of trees, following a logic of living space. Higher densities have more trees. The blocks are equidistant 28 meters parallel. Table 1 shows the vital areas, the number of trees per treatment and the number of trees per hectare in the implementation of the experiment.

Table 1: Treatments, living space, number of trees per treatment and number of trees per hectare.

\begin{tabular}{|c|c|c|c|}
\hline Treatments $(\mathrm{m} \times \mathrm{m})$ & Living Space $\left(\mathrm{m}^{2}\right)$ & $\mathrm{N}^{\mathrm{o}}$ of trees/Treatments & Trees/ha \\
\hline $1 \times 1,0$ & 1,0 & 200 & 10000 \\
\hline $2 \times 1,0$ & 2,0 & 104 & 5000 \\
\hline $2 \times 2,0$ & 4,0 & 104 & 2500 \\
\hline $3 \times 2,5$ & 7,5 & 72 & 1333 \\
\hline $3 \times 3,0$ & 9,0 & 72 & 111 \\
\hline $3 \times 3,5$ & 10,5 & 56 & 852 \\
\hline $4 \times 3,0$ & 12,0 & 56 & 714 \\
\hline $4 \times 3,5$ & 14,0 & 56 & 625 \\
\hline $4 \times 4,0$ & 16,0 & 56 & \\
\hline
\end{tabular}

First an inventory was compiled by treatment, measuring 25 trees from the center of each treatment to avoid the edge effect. From the data obtained from 25 central trees of each treatment, we chose to classify in diameter classes per spacing and we used the Sturges equation to determine the number of classes:

(1) $k=1+3,322(\log n)$

$\mathrm{k}=$ Number of Classes; $\mathrm{n}=$ Number of trees per treatment; $\log =$ Logarithm of decimal base.

Data was collected in June and July 2012 (population of 9 year olds), choosing a tree by each diameter class (9 classes for each treatment - Table 2) from the diameter distribution, specific to each treatment. It was considered data collection regardless of the blocks, using completely randomized design (CRD). This decision was also grounded in analyzes by LIMA (2010). He found no statistical differences between the blocks and therefore the experiment can be considered as a CRD. 


\begin{tabular}{|c|c|c|c|c|c|c|c|c|c|c|}
\hline \multirow{2}{*}{\multicolumn{2}{|c|}{$\begin{array}{c}\text { Treatments } \\
(\mathrm{m} \times \mathrm{m})\end{array}$}} & \multicolumn{9}{|c|}{ Diameter classes $(\mathrm{cm})$} \\
\hline & & 1 & 2 & 3 & 4 & 5 & 6 & 7 & 8 & 9 \\
\hline $1 \times 1,0$ & $\left(1 \mathrm{~m}^{2}\right)$ & $3,0-4,9$ & $5,0-6,9$ & $7,0-8,9$ & $9,0-10,9$ & $11,0-12,9$ & $13,0-14,9$ & $15,0-16,9$ & $17,0-18,9$ & $19,0-20,9$ \\
\hline $2 \times 1,0$ & $\left(2 \mathrm{~m}^{2}\right)$ & $5,0-6,9$ & $7,0-8,9$ & $9,0-10,9$ & $11,0-12,9$ & $13,0-14,9$ & $15,0-16,9$ & $17,0-18,9$ & $19,0-20,9$ & $21,0-22,9$ \\
\hline $2 \times 2,0$ & $\left(4 \mathrm{~m}^{2}\right)$ & $6,0-7,9$ & $8,0-9,9$ & $10,0-11,9$ & $12,0-13,9$ & $14,0-15,9$ & $16,0-17,9$ & $18,0-19,9$ & $20,0-21,9$ & $22,0-23,9$ \\
\hline $3 \times 2,5$ & $\left(7,5 \mathrm{~m}^{2}\right)$ & $10,0-11,9$ & $12,0-13,9$ & $14,0-15,9$ & $16,0-17,9$ & $18,0-19,9$ & $20,0-21,9$ & $22,0-23,9$ & $24,0-25,9$ & $26,0-27,9$ \\
\hline $3 \times 3,0$ & $\left(9 \mathrm{~m}^{2}\right)$ & $9,0-11,9$ & $12,0-14,9$ & $15,0-17,9$ & $18,0-20,9$ & $21,0-23,9$ & $24,0-26,9$ & $27,0-29,9$ & $30,0-32,9$ & $33,0-35,9$ \\
\hline $3 \times 3,5$ & $\left(10,5 \mathrm{~m}^{2}\right)$ & $10,0-12,9$ & $13,0-15,9$ & $16,0-18,9$ & $19,0-21,9$ & $22,0-24,9$ & $25,0-27,9$ & $28,0-30,9$ & $31,0-33,9$ & $34,0-36,9$ \\
\hline $4 \times 3,0$ & $\left(12 \mathrm{~m}^{2}\right)$ & $14,0-15,9$ & $16,0-17,9$ & $18,0-19,9$ & $20,0-21,9$ & $22,0-23,9$ & $24,0-25,9$ & $26,0-27,9$ & $28,0-29,9$ & $30,0-31,9$ \\
\hline $4 \times 3,5$ & $\left(14 \mathrm{~m}^{2}\right)$ & $15,0-16,9$ & $17,0-18,9$ & $19,0-20,9$ & $21,0-22,9$ & $23,0-24,9$ & $25,0-26,9$ & $27,0-28,9$ & $29,0-30,9$ & $31,0-32,9$ \\
\hline $4 \times 4,0$ & $\left(16 \mathrm{~m}^{2}\right)$ & $15,0-16,9$ & $17,0-18,9$ & $19,0-20,9$ & $21,0-22,9$ & $23,0-24,9$ & $25,0-26,9$ & $27,0-28,9$ & $29,0-30,9$ & $31,0-32,9$ \\
\hline
\end{tabular}

Altogether 81 trees were felled down, and then cubed. Diameters werw measured at the absolut heights 0,1 $\mathrm{m}$ and $1.3 \mathrm{~m}$ from deground and at the relative heights of $15 \%, 25 \%, 35 \%, 45 \%, 55 \%, 65 \%, 75 \%, 85 \%, 95 \%$ of the total height. Volumes were calculated by the Smalian equation.

Artificial form factor for each tree, was obtained by dividing the total volume outside bark in relation to the volume of a cylinder based on the DBH cross sectional area and total height.

$f f_{1,3}=\frac{V(\text { rig. })}{V(\text { cil. })}$

Wherein: $f f_{1,3}=$ Artificial form factor / $V$ (rig.): volume obtained - by the Smalian method $\left(\mathrm{m}^{3}\right) / V($ cil. $)$ : Cylinder volume based on the total height and cross sectional area at DBH.

After obtaining the artificial form factor $\left(f f_{1,3}\right)$ of each tree, it was estimated the average form factor for treatment (living space). Curves were constructed to illustrate the influence of density on the shape of the trees (living space $\mathrm{x} f f_{1,3}$ ).

Bartlett's test was used to verify the homogeneity of variance of the data at $1 \%$ of significance level. After the Bartlett's test, we then applied the analysis of variance (ANOVA) which was used to evaluate the effect of spacing on the form factor at 9 years old. When the ANOVA F test was significant, we applied the Duncan test, also at the $1 \%$ level of significance to check for differences between the means of treatments.

\section{RESULTS AND DISCUSSION}

Table 3 presents the form factor values for each treatment and its nine repetitions. The maximum value was found in the living space of $1 \mathrm{~m}^{2}(0,645)$ and the lowest in living space $10,5 \mathrm{~m}^{2}(0,397)$, corresponded to a difference of $38,54 \%$ between these amplitudes.

Table 3: Artificial form factor at nine years of age for each repetition and treatment (spacing).

\begin{tabular}{|c|c|c|c|c|c|c|c|c|c|c|}
\hline \multicolumn{2}{|c|}{ Treatment } & \multicolumn{9}{c|}{ Replays } \\
\hline \multicolumn{2}{|c|}{$(\mathrm{m} \times \mathrm{m})$} & 1 & 2 & 3 & 4 & 5 & 6 & 7 & 8 & \multicolumn{1}{c|}{9} \\
\hline $1 \times 1,0$ & $\left(1 \mathrm{~m}^{2}\right)$ & 0,492 & 0,544 & 0,507 & 0,479 & 0,645 & 0,646 & 0,587 & 0,478 & 0,495 \\
\hline $2 \times 1,0$ & $\left(2 \mathrm{~m}^{2}\right)$ & 0,570 & 0,465 & 0,507 & 0,462 & 0,563 & 0,488 & 0,505 & 0,571 & 0,424 \\
\hline $2 \times 2,0$ & $\left(4 \mathrm{~m}^{2}\right)$ & 0,497 & 0,538 & 0,428 & 0,543 & 0,477 & 0,528 & 0,513 & 0,519 & 0,508 \\
\hline $3 \times 2,5$ & $\left(7,5 \mathrm{~m}^{2}\right)$ & 0,448 & 0,450 & 0,473 & 0,423 & 0,556 & 0,524 & 0,528 & 0,507 & 0,445 \\
\hline $3 \times 3,0$ & $\left(9 \mathrm{~m}^{2}\right)$ & 0,454 & 0,427 & 0,442 & 0,471 & 0,455 & 0,449 & 0,498 & 0,469 & 0,508 \\
\hline $3 \times 3,5$ & $\left(10,5 \mathrm{~m}^{2}\right)$ & 0,404 & 0,397 & 0,449 & 0,475 & 0,425 & 0,468 & 0,425 & 0,488 & 0,473 \\
\hline $4 \times 3,0$ & $\left(12 \mathrm{~m}^{2}\right)$ & 0,444 & 0,479 & 0,437 & 0,526 & 0,488 & 0,446 & 0,422 & 0,400 & 0,416 \\
\hline $4 \times 3,5$ & $\left(14 \mathrm{~m}^{2}\right)$ & 0,430 & 0,461 & 0,458 & 0,453 & 0,479 & 0,469 & 0,483 & 0,532 & 0,458 \\
\hline $4 \times 4,0$ & $\left(16 \mathrm{~m}^{2}\right)$ & 0,428 & 0,509 & 0,494 & 0,426 & 0,418 & 0,465 & 0,449 & 0,484 & 0,441 \\
\hline
\end{tabular}

From the Bartlett test, there was not rejected of $\mathrm{H} 0$ for the form factor data at the level of $\alpha=0.01$, where this way could be subjected to analysis of variance (ANOVA). The F test in Table 4 indicates statistically significant differences between treatments $(\mathrm{p}<0.01)$.

Table 4: Analysis of variance (ANOVA) for the completely randomized design (CRD).

\begin{tabular}{|c|c|c|c|c|}
\hline Variation source & GL & SQ & QM & F \\
\hline Treatments & 8 & 0,07296 & 0,00912 & $5,1058 * *$ \\
\hline Residue & 72 & 0,12861 & 0,00179 & \\
\hline Total & 80 & 0,20158 & & \\
\hline
\end{tabular}

** significant at $1 \%$ probability $(p<=0,01)$

From the ANOVA results, the living space significantly influences the trunk form. The Duncan test (p <= 0,01 ) was then applied to the average form factors in different spacing at nine years of age (Table 5). 
Table 5: Artificial Form Factors average of Pinus taeda L. by each spacing and the results of the Duncan test.

\begin{tabular}{|c|c|c|c|}
\hline \multirow{2}{*}{\multicolumn{2}{|c|}{$\begin{array}{c}\text { Treatments } \\
(\mathrm{m} \times \mathrm{m}) \\
\end{array}$}} & \multirow{2}{*}{\multicolumn{2}{|c|}{ Form Factor }} \\
\hline & & & \\
\hline $1 \times 1$ & $\left(1 \mathrm{~m}^{2}\right)$ & 0,541 & $\mathrm{a}$ \\
\hline $2 \times 1$ & $\left(2 \mathrm{~m}^{2}\right)$ & 0,506 & $\mathrm{ab}$ \\
\hline $2 \times 2$ & $\left(4 \mathrm{~m}^{2}\right)$ & 0,505 & $\mathrm{ab}$ \\
\hline $3 \times 2,5$ & $\left(7,5 \mathrm{~m}^{2}\right)$ & 0,483 & $\mathrm{bc}$ \\
\hline $3 \times 3$ & $\left(9 m^{2}\right)$ & 0,463 & $\mathrm{bc}$ \\
\hline $3 \times 3,5$ & $\left(10,5 \mathrm{~m}^{2}\right)$ & 0,444 & $\mathrm{c}$ \\
\hline $4 \times 3$ & $\left(12 \mathrm{~m}^{2}\right)$ & 0,450 & $\mathrm{c}$ \\
\hline $4 \times 3,5$ & $\left(14 \mathrm{~m}^{2}\right)$ & 0,469 & $\mathrm{bc}$ \\
\hline $4 \times 4$ & $\left(16 \mathrm{~m}^{2}\right)$ & 0,466 & $\mathrm{c}$ \\
\hline \multicolumn{2}{|c|}{$\mathrm{CV} \%$} & 8,800 & \\
\hline
\end{tabular}

Means followed by the same letter are not statistically different from each other by Duncan test at $1 \%$ probability (p <0.01).

Ferreira et al. (1997) found similar results for Eucalyptus spp., and the form factor values decreased as the spacing increased, ie, more cylindrical trunk in a narrower spacing.

Van Laar (1978) cited by Balloni (1980) working with Pinus patula also found that the form factor decreased as the spacing increases. This change could mean an increase of almost $10 \%$ in real volume, highlighting the importance of evaluating such a feature in the study of vital space.

Figueiredo et al. (2005) conducted a study with estimates of the form factor in stands of Tectona grandis in the state of Acre, where the form factor presents a closer relationship to the cylindrical shape for younger trees, whereas for older individuals the conicity is higher.

The form factor has high importance in the final uses of the wood, where more tapered logs generate a smaller quantity of processed wood (sawn, veneers etc.) for any minimum diameter use in any country. This reflects a loss in the quantity of processed wood, consequently economic losses.

Spacings around $7,5 \mathrm{~m}^{2}$ is a focal point in reducing the effects on the conicity of the trees. By using the Duncan test the form factor shows that living space differs only the average shape of the shaft in denser space (1 $\left.\mathrm{m}^{2}\right)$.

To better visualize the fluctuation of trunk form at 9 years of age for each treatment, we used a column chart (Figure 2). There has been a decrease in the form factor as living space increases, supporting the theory that the more is cylindrical the trunk the smaller living spaces.

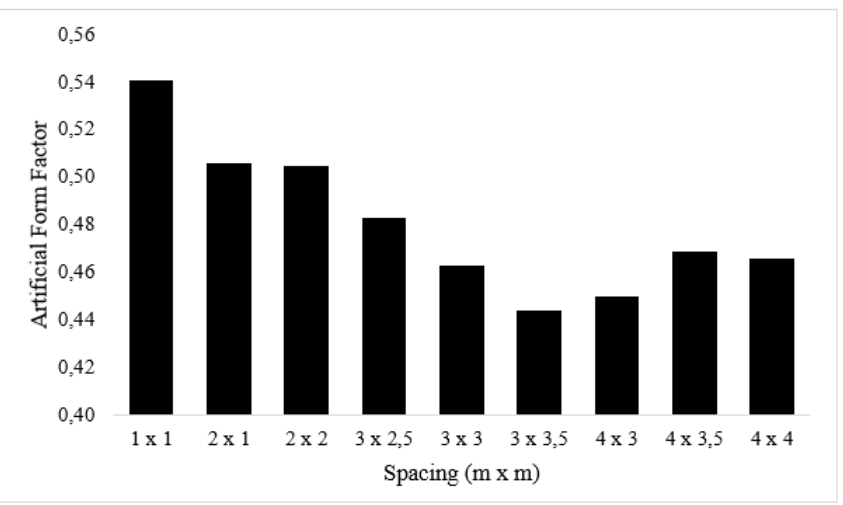

Fig. 2: Average artificial form fator by each spacing at 9 years of age.

What was found was a variation of approximately $17 \%$ in form factor between the largest and smallest spacings. This means that at the age of nine years, less dense spacing trunks grow $54 \%$ of the cylinder volume, while larger spacings produce shaft with about $17 \%$ more tapering.

Nogueira (2008), studing the influence of initial spacing in Pinus taeda plataions regarding the shape of the trunk, found that higher initial living spaces result in higher conicity, while under high shaft, not applying thinning regime is in relation to smaller spacing.

\section{Conclusions:}

The form factor at 9 years old indicated that higher initial densities result in more cylindrical stems up to $17 \%$ when compared to lower densities. L. shaft.

Living spaces around 7,5 $\mathrm{m}^{2}$ are adequate to reduce the effect of spacing on the form factor of Pinus taeda 


\section{REFERENCES}

Balloni, E.A., J.W. Simoes, 1980. O espaçamento de plantio e suas implicações silviculturais. Série técnica. IPEF, Piracicaba, 1(3): 1-16.

De Cesaro, A., O.A. Engel, C.A.G. Finger, P.R. Schneider, 1994. Comparação dos métodos de amostragem de área fixa, relascopia, e de seis árvores, quanto a eficiência, no inventário florestal de um povoamento de Pinus sp. Ciência Florestal, Santa Maria, 4(1): 97-108.

Figueiredo, E.O., J.R.S. Scolforo, A.D. Oliveira, 2005. de. Estimativa do percentual de casca e do fator de forma em povoamentos jovens de Teca (Tectona grandis L.f). Rio Branco, Acre (Brasil). Embrapa Acre, 5 (Embrapa Acre. Comunicado Técnico, 165).

Flach, F.D., 2007. Crescimento juvenil da regeneração espontânea de Pinus elliottii eng. var. elliottii sob níveis de desbaste, no litoral norte do Rio Grande do Sul. 56p. Dissertação (Mestrado em Fitotecnia)Universidade Federal do Rio Grande do Sul, Porto Alegre.

Dossa, D., 2012. Importância sócio-econômica e ambiental do Pinus taeda L. Disponível em: < http://sistemasdeproducao.cnptia.embrapa.br/FontesHTML/Pinus/CultivodoPinus/11_importancia_socio_econo mica.htm>. Acesso em: 17 de ago.

Ferreira, G.W., 1996. Qualidade da celulose kraft-antraquinona de Eucalyptus dunnii Maiden plantado em cinco espaçamentos em relação ao Eucalyptus grandis Hill ex Maiden e Eucalyptus saligna Smith, 128. Dissertação (Mestrado em Ciências Florestais) - Universidade Federal de Santa Maria, Santa Maria.

Figueiredo Filho, A., 1991. Influência da resinagem no crescimento de Pinus elliottii Engelm. var. elliottii e sua avaliação econômica. Curitiba: UFPR - Setor de Ciências Agrárias, 138.

Finger, C.A.G., 2006. Biometria florestal. Santa Maria: UFSM, 239.

Macedo, R.L.G., 2005. Desenvolvimento inicial de Tectona grandis L.f. (teca) em diferentes espaçamentos no município de Paracatu, MG. Cerne, Lavras, 11(1): 61-69.

Machado, S.A., E. Urbano, M.B. Conceição, 2005. Comparação de métodos de estimativas de volume para Pinus oocarpa em diferentes idades e diferentes regimes de desbastes. Boletim de Pesquisa Florestal, Colombo, 50: 81-98.

Nogueira, G.S., H.G. Leite, G.G. Reis, A.M. Moreira, 2008. Influência do espaçamento inicial sobre a forma do fuste de árvores de Pinus taeda L. Revista Árvore, Viçosa, 32(5): 855-860.

Schneider, P.R., P.S.P. Schneider, 2008. Introdução ao Manejo florestal. Santa Maria: Ed. FACOS, 566.

Vilas Bôas, O., Max, J.C.M. Melo, A.C.G. de, 2009. Crescimento comparativo de espécies de Eucalyptus e Corymbia no município de Marília, SP. Revista do Instituto Florestal, São Paulo, 21(1): 63-72. 